\title{
28. CORRELATIONS BETWEEN SITES ON THE EASTERN FALKLAND PLATEAU BY MEANS OF SEISMIC REFLECTION PROFILES, LEG 36, DSDP
}

\author{
P.F. Barker, Department of Geological Sciences, University of Birmingham, England
}

\begin{abstract}
Cored sections from three sites $(327,329$, and 330) on the eastern elevated part of the Falkland Plateau (the Maurice Ewing Bank) are correlated by means of two complementary reflection profiles which pass through all three sites. Limitations are imposed upon the precision of the correlation by defects of sampling at the sites and by the characteristics of the reflection profiles, but the results are of value. None of the principal conclusions drawn from preliminary studies of the cored material is contradicted by the analysis and most are confirmed or extended. In particular, the Mid to Late Jurassic marine transgression observed at Site 330 is put into context, as being sampled on a basement high close to the margin of a 1.5 to $2 \mathrm{~km}$ deep basin floored probably by continental crust. This dichotomy of shelf and basin province, which may apply over the entire plateau, was in existence by the Late Jurassic and has remained undisturbed by relative movement since that time. The restricted circulation evident in Upper Jurassic and Lower Cretaceous sediments on the shelf probably occurred also throughout the basin province and implies confinement during that period by land barriers to the south and west. In the early Albian circulation improved, as the Maurice Ewing Bank subsided and as a deep-water connection was made to the east between the developing South Atlantic and Indian oceans. These events resulted in largely pelagic sedimentation at the site, tending to degrade the topographic distinction between shelf and basin, which earlier, largely terrigenous sedimentation had preserved. An Upper Cretaceous condensed section suggests nondeposition below the CCD, rather than erosion, but a gradual increase in bottom currents from the Maestrichtian through the Cenozoic is evident in the profiles. The sea bed at present is of all ages from Late Cretaceous to late Miocene in the vicinity of the sites, a result of submarine erosion, largely if not entirely of Neogene age. It is speculated that the greater part of the sedimentary fill in the basin province is of biogenic oozes of Maestrichtian and Paleogene age, continuous with similar sediments on the shelf (elevated region) before the period of submarine erosion. Although the data are consistent with a mid-Cenozoic opening of Drake Passage, many other secondary factors may have influenced sedimentation, and it is not possible at the sites or along the line of section to make a more precise estimate of when a consequent sharp increase in the strength of bottom currents might have taken place.
\end{abstract}

\section{INTRODUCTION}

During Leg 36 of the Deep Sea Drilling Project, Glomar Challenger drilled at three sites on the southwestern flank of the isolated eastern elevated part of the Falkland Plateau (see Figure 1). Site 327, part of the original program, was drilled first, then forced abandonment of the more southerly part of the leg made time for additional, complementary sites, proposed by the shipboard party. Site 329 sampled the Neogene section which Site 327 had deliberately avoided, and Site 330 extended the section to basement in a location where the deeper layers were more accessible. Thus, in combination the sites provide a complete section through sediment of the more elevated part of the eastern Falkland Plateau (the Maurice Ewing Bank). The purpose of this paper is to effect that combination by means of two complementary reflection profiles which pass through or close to all three sites.

The two-way travel time to a particular horizon within the cored sedimentary sequence is first calculated at each site, by means of the measured acoustic velocities of the cored material. Lithologic and stratigraphic boundaries down the hole are then related to the reflection profiles, and specific reflectors are identified. These reflectors are traced first between sites on the profiles, to check the correlations, and then beyond sites as far as is possible. The results are presented as two interpreted time sections, one for each reflection profile, which are examined for paleogeo- 


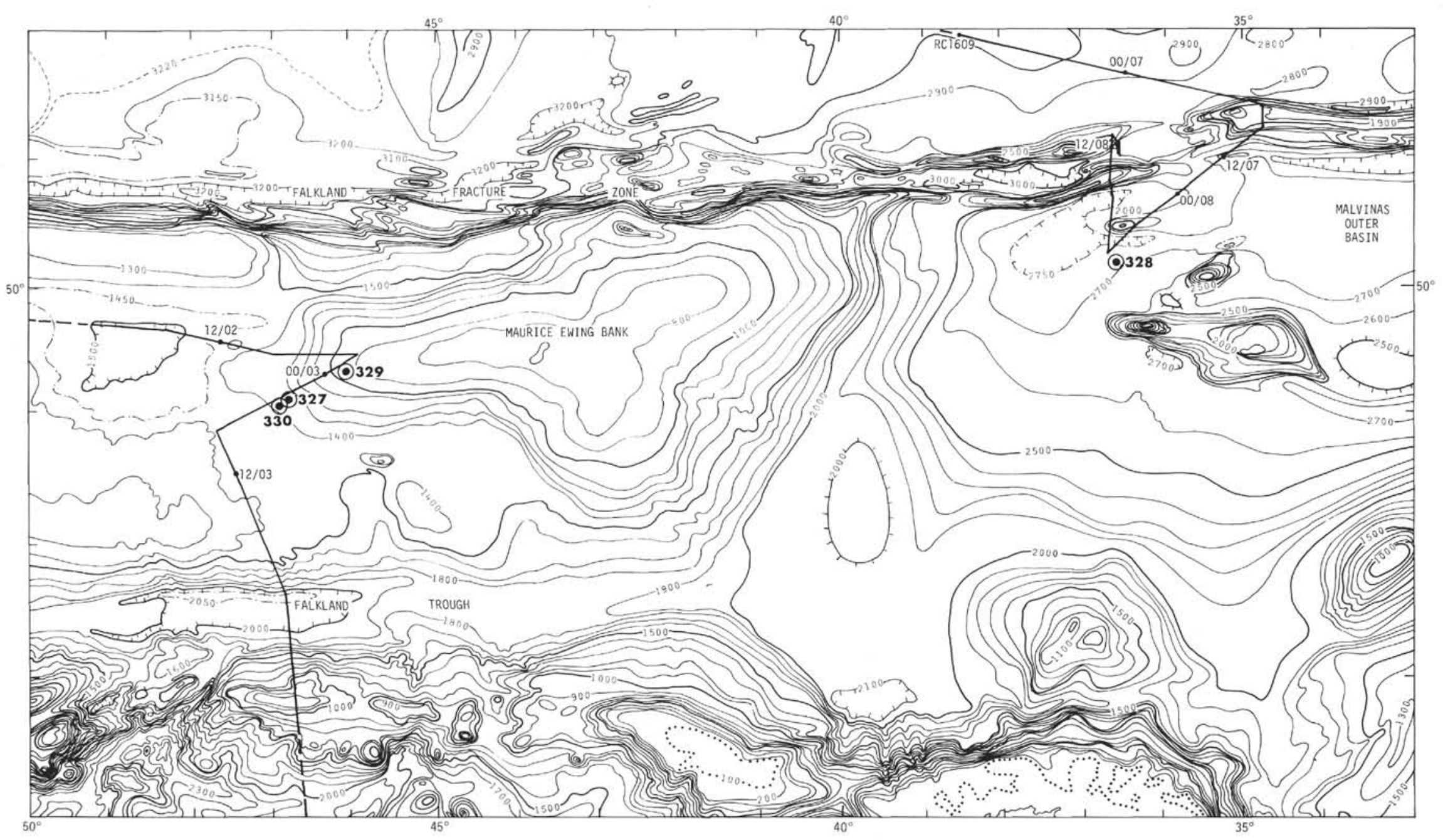

Figure 1. Bathymetry of the Falkland Plateau and location of drilling sites. 
graphic insights with which to test and extend conclusions derived from examination of the cores alone.

\section{REFLECTION PROFILES}

Two profiles are considered here: the first is that section of the RC 1606 profile (Lamont-Doherty Geological Observatory) which had been used in selecting the positions of all three sites, and the second is part of that acquired by Glomar Challenger on passage between sites. The relationship between ship tracks and sites is shown in Figure 2, and the profiles themselves form Figures 3 and 4 . The regional situation of the sites can be seen in Figure 1.

\section{Robert Conrad (RC 1606) Reflection Profile}

Having approached the Maurice Ewing Bank from the west, the ship altered course southwestward $\left(243^{\circ}\right)$, from near the crest of the bank's western nose, to traverse what the bathymetry suggests is a dip section, extending into the deeper "basin" province of the Falkland Plateau. A further course alteration (to $158^{\circ}$ ) took the ship away from the plateau, across the Falkland Trough and north Scotia Ridge. The track passes within $2 \mathrm{~km}$ of Sites 329 and 330 , and within 1 $\mathrm{km}$ of Site 327; the low dips of acoustic reflectors in Figure 3 provide some justification for assuming, in all that follows, that track and sites are effectively coincident.

The reflection profile was obtained using a largevolume, low-pressure airgun and single-channel recording. The hydrophone signal was half-wave rectified and bandpass-filtered before variable density display. A second record, using slightly different filter settings, was made available to the author, in addition to that displayed in Figure 3. Dominant frequencies within the record are 25 to $35 \mathrm{~Hz}$ and the primary pulse extends over $0.2 \mathrm{sec}$ of two-way travel time (TW). These characteristics provide excellent penetration of thick sediments (up to $3 \mathrm{sec}$ TW in parts of Figure 3), but poor resolution of thin layers. Lack of magnetic tape recording precludes any improvement in resolution by deconvolution with the primary pulse and, as may be anticipated, the profusion of reflections within the sediments in the vicinity of the sites makes real, unambiguous correlation with the core lithology difficult to achieve. To a large extent, however, these problems are overcome by the use of the other available reflection profiles.

\section{Glomar Challenger Reflection Profiles}

The weather was bad during both the approach to and departure from Site 327, and the reflection profiles obtained (displayed elsewhere, Barker, this volume) are poor in quality and of no real value for correlation between sites. This is not true, however, of the reflection profiles obtained before and after drilling Sites 329 and 330. The ship approached Site 329 from the east, along the crest of the Maurice Ewing Bank and approximately parallel to the track followed between Sites 329 and 330 , which passed within $2 \mathrm{~km}$ of Site 327 (Figure 2). This line was extended a little beyond Site 330 on completion of drilling there, before the ship headed north for the Argentine Basin. The composite profile, displayed in Figure 4, was obtained using 2 Bolt airguns, of 10 and 40 in. ${ }^{3}$ capacity and charged to 2000 psi. The return signals from two hydrophone streamers were added, half-wave rectified, and filtered between 160 and $320 \mathrm{~Hz}$ before display (the section southwest of Site 330 was filtered between 80 and $160 \mathrm{~Hz}$ ). This pass band is higher than the peak frequencies of the output power spectra of the airguns, but is forced upon the shipboard operators by the large amount of shipgenerated noise at lower frequencies. The results are a dominant frequency of about $160 \mathrm{~Hz}$ and a primary pulse only $0.04 \mathrm{sec}$ long (bubble pulse frequency about $30 \mathrm{~Hz}$ ), which give relatively poor penetration of the sediments but much better resolution than in the RC 1606 profile. Two records were available to the author, the 4-sec display as shown in Figure 4 and a 10-sec display (shown in Barker, this volume).

Since the two profiles are effectively coincident in the region of the sites, they can be combined so as to overcome their respective weaknesses. In particular, in attempting to correlate lithologic and biostratigraphic boundaries down the holes with specific reflections, and again in tracing reflectors away from sites, the Glomar Challenger profile is considered first, so that its superior resolution can then be used to help distinguish between primary, bubble pulse, and multiple reflections in the upper parts of the more complex RC 1606 profile.

A start for the correlation process is made in the site chapters in this Initial Report, in that a velocity-depth model is used to compare the stratigraphy with a reflection profile at each site. The treatment there is to some extent circumscribed by the site chapter format, however, and distorted by the need to maintain a chronological order. For the sake of clarity, there is some repetition here of that information.

\section{OBSERVATIONS AT SITES}

Before undertaking the comparison between profiles and sedimentary sequence at each site, it is necessary to consider briefly the errors and uncertainties in the process, as they apply here.

In the ideal situation, each site yields perfect logs of velocity and density down the hole, allowing the construction of a time-dependent $\log$ of the reflection coefficient. When convolved with the source function of the profiling system and filtered in simulation of the receiver response, this produces an exact duplicate of the reflection profile. In the absence of continuous downhole logging, production of such a log requires (a) continuous coring with $100 \%$ recovery and no drilling disturbance; (b) error-free shipboard measurements of density and vertical acoustic velocity on cores, at intervals small compared with the wavelength of the seismic energy; and (c) means of correcting for the effects on these measured properties of the change from in situ to atmospheric ambient pressure and temperature.

At the Falkland Plateau sites none of these criteria was met. Coring intervals varied between continuous and 1 in 14 , averaging 1 in 2, and of this, $56 \%$ (29\% of penetration) was recovered. Recovery was lowest in the 


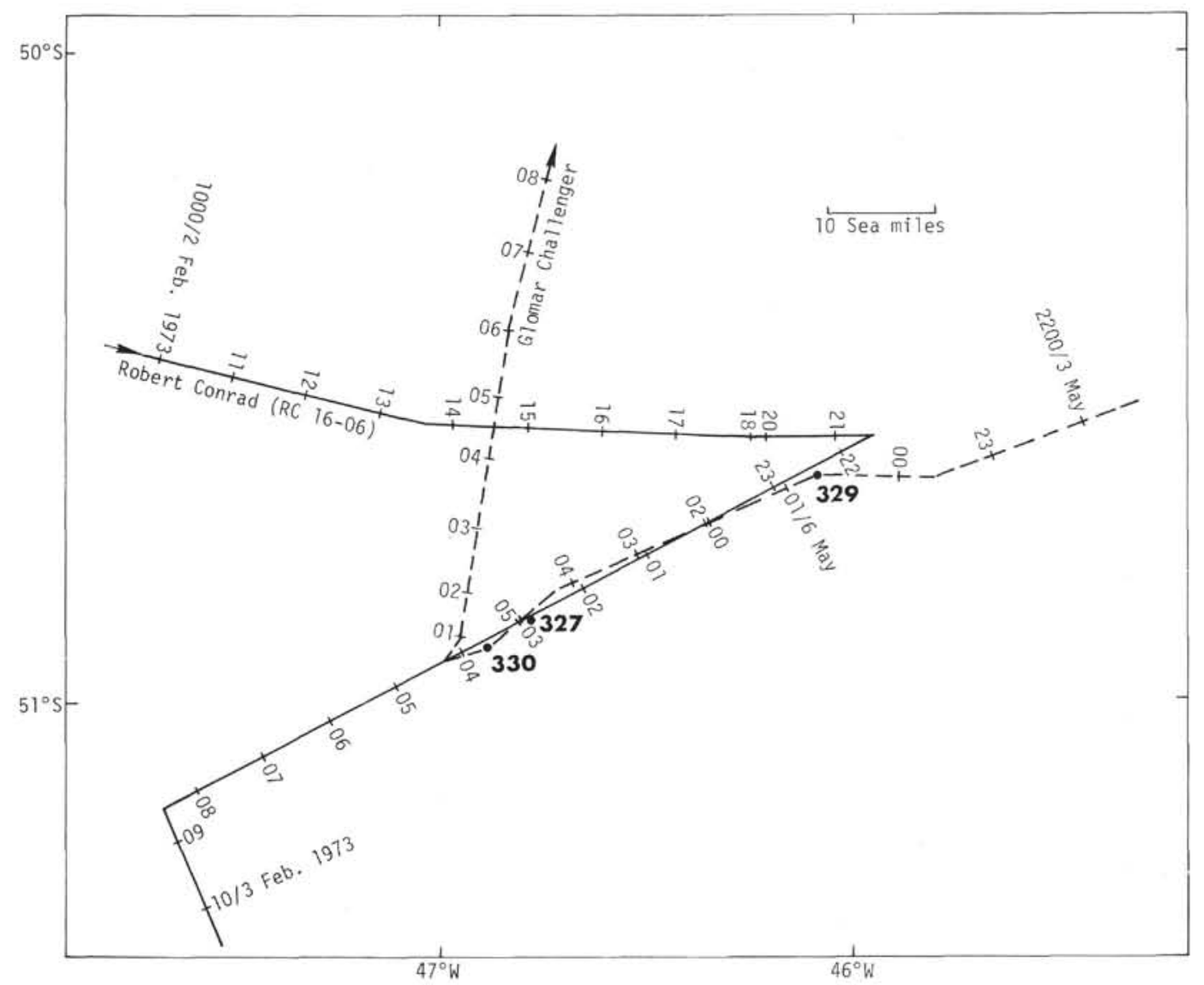

Figure 2. Location of drilling sites relative to Glomar Challenger and RC 1606 reflection profiles, eastern Falkland Plateau.

deeper parts of the holes and, in mixed lithologies, the harder chert and limestone bands were probably preserved preferentially. Obvious coring disturbance prevented measurement on any part of a few cores and less obvious disturbance elsewhere may have biased measured values. For the wavelengths of acoustic energy in use, an adequate sampling interval would have been 1 meter, which was achieved for some parts of the holes. Elsewhere measurements are sparse; there are 32 instances of measurement intervals greater than 20 meters and 5 of greater than 40 meters. A 40 -meter gap is equivalent to about $0.045 \mathrm{sec}$, or 7 cycles of the dominant frequency in the Glomar Challenger profile, 1.3 cycles for RC 1606.

The acquisition of shipboard measurements of physical properties is described elsewhere (Lonardi, this volume), including more detailed discussion of measurement errors and the extent to which shipboard measurements represent in situ values. It is assumed here that errors in shipboard velocity measurements are small $(\leqq 1 \%)$ and unbiased. Moreover, it is considered that the velocity decrease resulting from the transfer of the core from in situ to atmospheric pressure is small at such small depths of burial, and is offset by the use of velocity measurements made parallel to bedding (in situ horizontal). The very small minority of laboratory measurements made perpendicular to bedding (in situ vertical, as encountered by the seismic energy of the profiles) proved to be about $2 \%$ lower than parallel-tobedding measurements, on the same samples, for the major lithologies.

In summary, the view is taken here that the quantity, quality, and distribution of physical properties are, inevitably, inadequate for the "ideal" process of generation of a synthetic seismogram by convolution to be worthwhile. A simpler process is adopted, of fitting a crude model of the variation of velocity with depth to the observed values. The model is unbiased for systematic errors, in accord with the assumptions outlined above, and weighted only to take account of the relative abundances of the components of a mixed lithology; measured values and models for all three sites are shown in Figure 5. Velocities greater than 2.4 $\mathrm{km} / \mathrm{sec}$, confined largely to the minor lithologies such as limestones and cherts, and probably oversampled, are plotted on the depth axis in Figure 5 to save space.

Larger errors accompany density rather than velocity measurements and, at least in the less consolidated sediments, density varies as much as or more than velocity. However, velocity and density appear to vary in phase with each other, the controlling factor in both cases being water content. In the main, therefore, acoustic impedance varies in phase with velocity, and strong reflections should occur mainly at times corresponding to the depths of large velocity changes, as shown in Figure 5. 

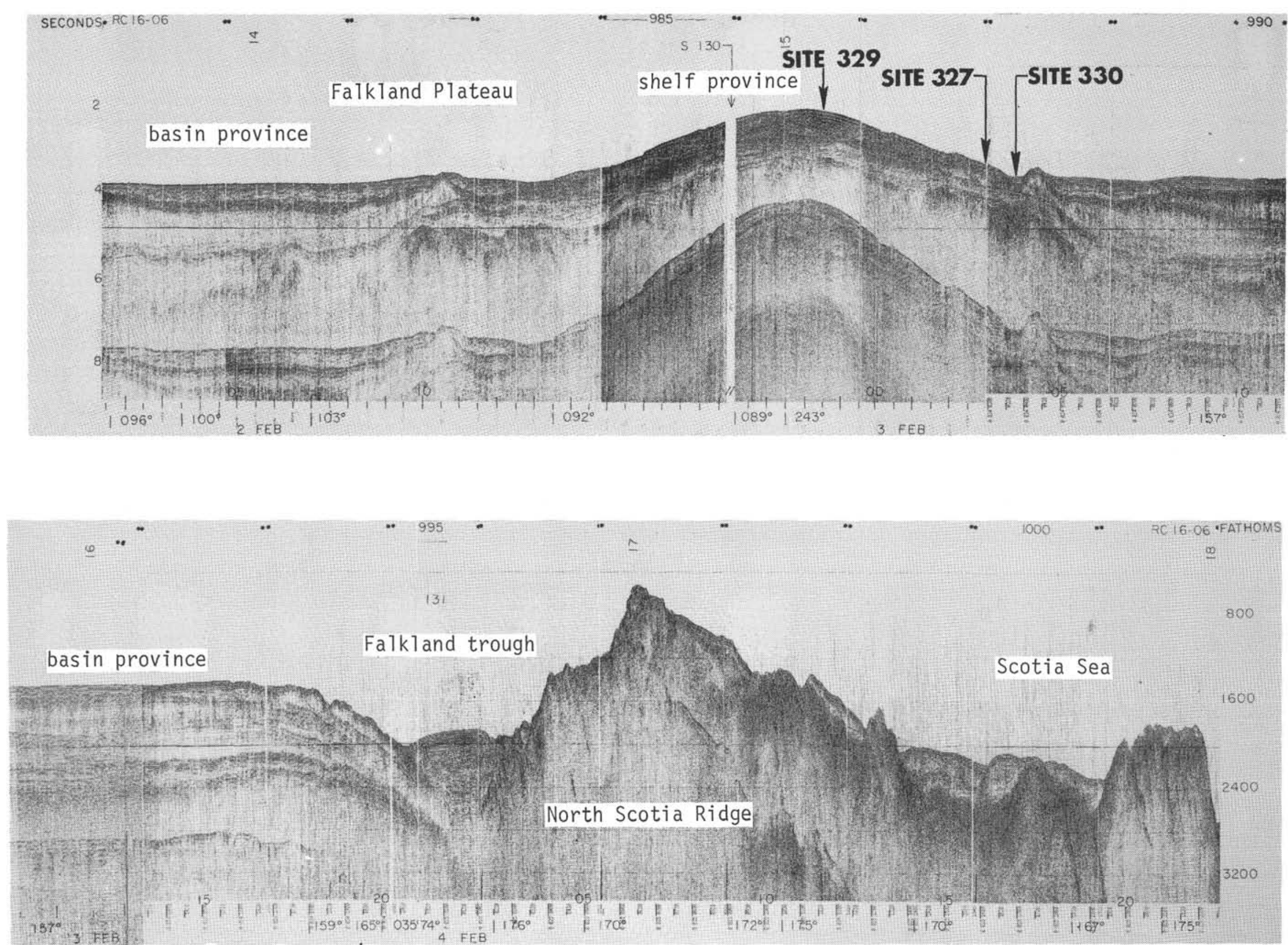

Figure 3. RC 1606 reflection profile, eastern Falkland Plateau, with drilling sites marked. 

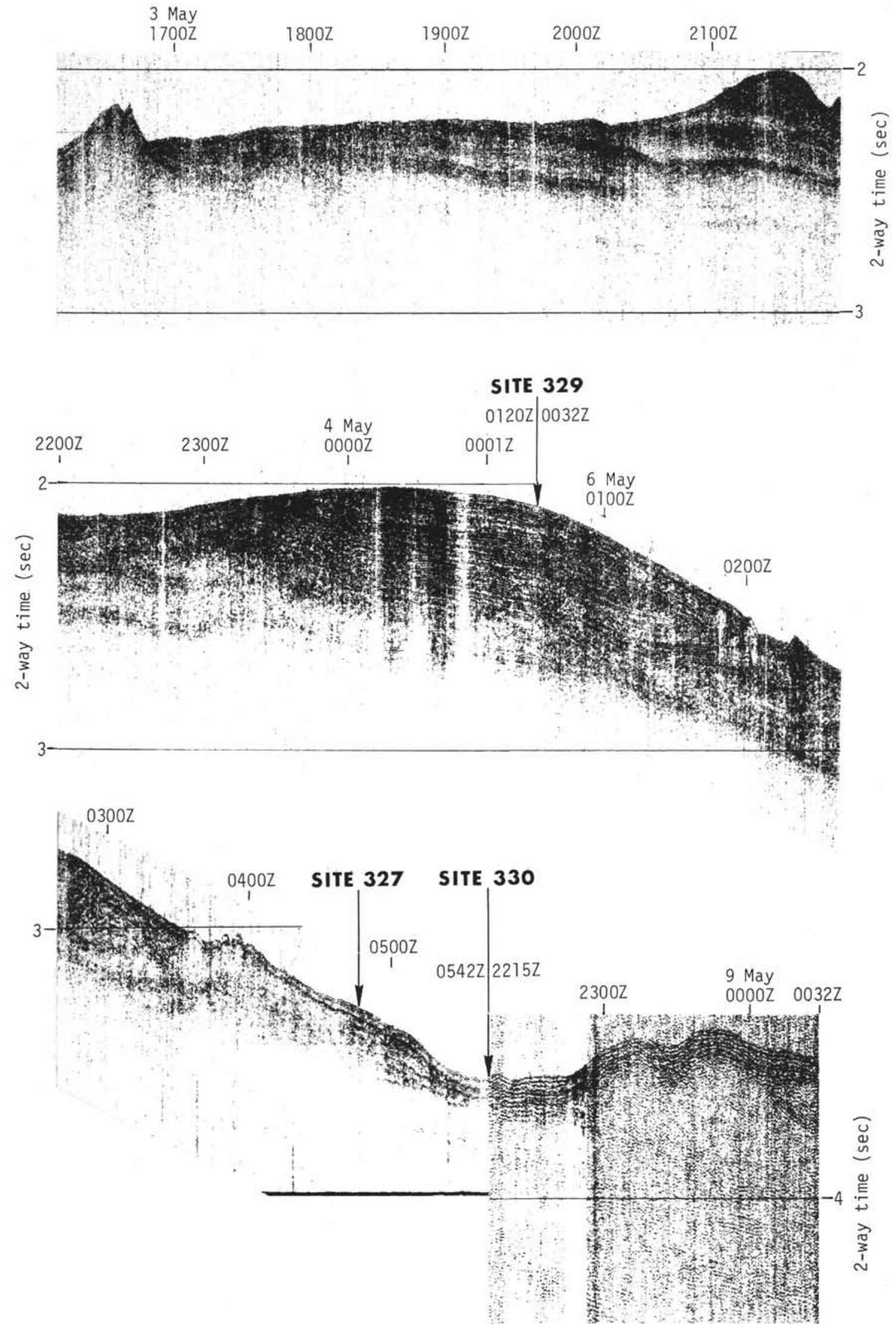

Figure 4 Glomar Challenger reflection profile, eastern Falkland Plateau, with drilling sites marked. 
A well-defined, strong reflection in the profiler record, identified unambiguously with a sharp acoustic impedance contrast within a well-sampled section of a hole, would in theory provide a "calibration" of the process, a check on the above assumptions. As will become obvious however, this opportunity is not presented at the Falkland Plateau sites. Because of the low proportion of cored intervals and imperfect recovery, many of the largest velocity contrasts occur across coring gaps, as do many lithologic and stratigraphic boundaries. The considerable leeway which this introduces into the location of a reflector usually prevents any but the grossest checks on velocities in the overlying beds. A 40 -meter measurement gap at 200 meters, for example, represents $\pm 10 \%$ uncertainty in velocity down to a reflector in that inter$\mathrm{val}$, which exceeds greatly the expected measurement error; some of this uncertainty, in proportion to the velocity contrast, is propagated downward in the section so that, to some extent, the uncertainties are cumulative.
The gross effect is of ambiguity in the identification of reflectors in Figures 3 and 4, leading to a loss of effective resolution. Uncertainty is greatest in coring gaps, a common-sense conclusion, but a coring gap in the upper part of a hole generates an uncertainty which affects all deeper interfaces to some extent.

The measured compressional-wave velocities for each site, together with the simplified velocity-depth models fitted to them, are shown in Figure 5. Table 1 lists the depths and two-way travel times (calculated from the models) to the more important lithologic and stratigraphic boundaries down each hole and notes also the extent to which these correlate with prominent reflectors. These boundaries are also marked against a sample of both the Glomar Challenger and RC 1606 profiles in Figures 6, 7, and 8, for Sites 329, 327, and 330 , respectively.

\section{Site $329\left(50^{\circ} 39.31^{\prime} \mathrm{S}, 4^{\circ} 05.73^{\prime} \mathrm{W}, 1519 \mathrm{~m}\right.$ depth $)$}

Site 329 was located to sample the bank of younger sediments, apparent on the RC 1606 reflection profile

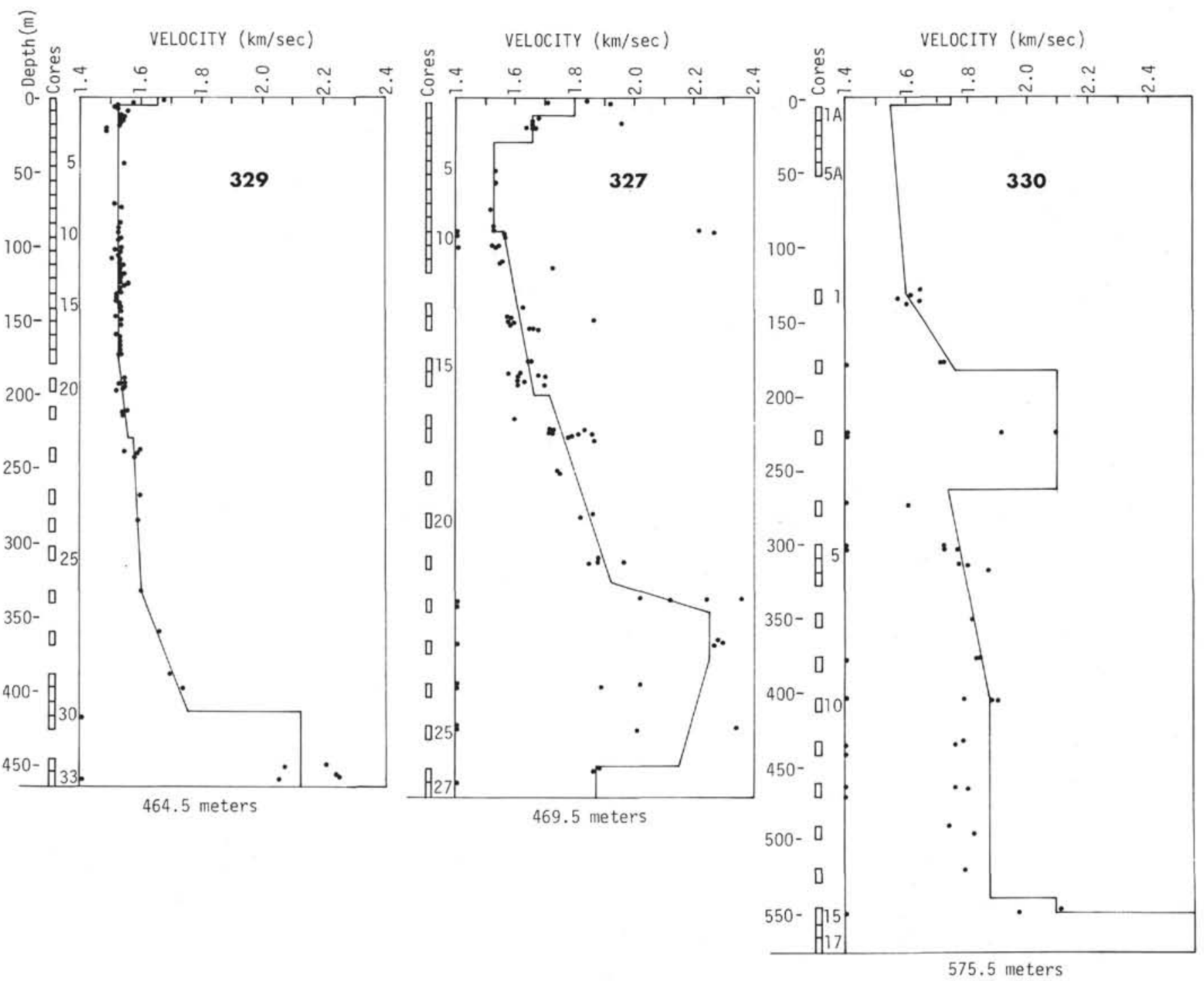

Figure 5. Measured p-wave velocities and model velocity-depth function, Sites 327, 329, and 330. 
TABLE 1

Depths and Times to Lithologic and Stratigraphic Boundaries and Reflectors

\begin{tabular}{|c|c|c|c|c|}
\hline Core & $\begin{array}{c}\text { Lithological or } \\
\text { Biostratigraphic Boundary }\end{array}$ & $\begin{array}{l}\text { Depth } \\
(\mathrm{m})\end{array}$ & $\begin{array}{c}\text { Time } \\
\text { (sec TW) }\end{array}$ & Comment \\
\hline \multicolumn{5}{|c|}{ Site 329} \\
\hline $20-21$ & $\begin{array}{l}\text { Middle to late Miocene, } \\
\text { in ooze sequence }\end{array}$ & 199-208 & $0.26-0.27$ & $\begin{array}{l}\text { Many sharp reflectors } \\
\text { none distinctive, } 0.265 \text { marked }\end{array}$ \\
\hline $27-28$ & $\begin{array}{l}\text { Oligocene/Eocene to middle } \\
\text { Miocene, Units } 1 \mathrm{D} \text { to } 2\end{array}$ & $362-388$ & $0.465-0.495$ & $\begin{array}{l}\text { Many reflectors but more diffuse, } \\
0.48 \mathrm{sec} \text { marked }\end{array}$ \\
\hline 32 & $\begin{array}{l}\text { Paleocene to Eocene, } \\
\text { in chalks }\end{array}$ & $447-450$ & 0.56 & Weak reflector does occur at $0.56 \mathrm{sec}$ \\
\hline 33 & Base of hole, Paleocene & 464.5 & 0.575 & - \\
\hline \multicolumn{5}{|c|}{ Site 327} \\
\hline $2-3$ & Paleocene-Eocene, in Unit 2 & 23 & 0.027 & In wavetrain of sea-bed reflection \\
\hline $9-10$ & $\begin{array}{l}\text { Maestrichtian-Paleocene, } \\
\text { Units } 4 \text { to } 5\end{array}$ & 90 & 0.113 & Many reflectors, none distinctive \\
\hline 13 & $\begin{array}{l}\text { ? Base Maestrichtian and } \\
\text { Unit } 5\end{array}$ & 139 & 0.175 & As above \\
\hline $21-22$ & Units 7 to 8 , Aptian-Albian & $315-336$ & $0.38-0.40$ & $\begin{array}{l}\text { Weaker } 0.39 \text {, stronger } 0.42 \text { reflectors } \\
\text { on both records, } 0.39 \mathrm{sec} \text { marked }\end{array}$ \\
\hline $25-26$ & $\begin{array}{l}\text { Velocity inversion in Unit } 8 \text {, } \\
\text { Aptian }\end{array}$ & $427-450$ & $0.48-0.50$ & $\begin{array}{l}\text { Strong reflector } 0.50 \text {, interference } \\
\text { from } 0.42 \mathrm{sec} \text { event }\end{array}$ \\
\hline- & Strong reflector $0.23 \mathrm{sec}$ & 184 & - & $\begin{array}{l}\text { Cores } 15-16 \text {, near top of Unit } 7 \text {, } \\
\text { Albian clay; no obvious cause }\end{array}$ \\
\hline 27 & Base of hole, Aptian & 469.5 & 0.52 & - \\
\hline \multicolumn{5}{|c|}{ Site 330} \\
\hline $2-3$ & Units 2 to 3 , Aptian-Albian & $180-225$ & $0.225-0.27$ & $\begin{array}{l}\text { Weak reflectors } 0.21,0.23 \mathrm{sec} \mathrm{GC} \text {, } \\
\text { interference on } \mathrm{RC} \text { record, } 0.22 \mathrm{sec} \\
\text { marked }\end{array}$ \\
\hline $3-4$ & $\begin{array}{l}\text { Velocity inversion in Unit } 3 \text {, } \\
\text { Aptian }\end{array}$ & $228-272$ & $0.27-0.31$ & $\begin{array}{l}\text { Reflector fairly strong } 0.31 \mathrm{sec} \text {, but } \\
\text { some irregularity in layering }\end{array}$ \\
\hline $4-5$ & $\begin{array}{l}\text { Oxfordian-Aptian apparent } \\
\text { hiatus in Unit } 3\end{array}$ & $275-301$ & $0.325-0.35$ & $\begin{array}{l}\text { No reflector seen but interference } \\
\text { from } 0.31 \text { sec event }\end{array}$ \\
\hline $10-11$ & Units 3 to 4 & $408-433$ & & No reflector seen \\
\hline $14-15$ & Units 4 to 5 & $525-547$ & $0.58-0.61$ & $\begin{array}{l}\text { Strong reflector } \sim 0.60 \mathrm{sec} \text {, but } \\
\text { weaker at site }\end{array}$ \\
\hline 15 & Basement granite-gneiss & 550 & 0.615 & Very weak, stronger beneath \\
\hline - & Strong reflector $0.11 \mathrm{sec}$ & 86 & - & $\begin{array}{l}\text { Above Core } 1 \text {, near top of Unit } 2 \text {, } \\
\text { Albian clay; no obvious cause }\end{array}$ \\
\hline
\end{tabular}

(Figure 3), but deliberately avoided at Sites 327 and 330 downslope. Coring at this site was continuous down to 180 meters and mainly intermittent from there to 464.5 meters. Recovery and velocity sampling were both good, and the velocity-depth model in Figure 5 is relatively well founded in consequence.

Below 5 meters of Recent siliceous ooze containing abundant glacial dropstones, the uppermost 370 meters is a sequence of biogenic calcareous and siliceous oozes (Units 1B, 1C) becoming a chalk in its lower part, and is of middle and late Miocene age. Below 388 meters lies Unit 2, a nanno chalk of Paleocene to middle or early Miocene age, much less rapidly deposited than the overlying Miocene oozes and possibly containing hiatuses.

Measured compressional wave velocities are high within the thin Unit 1A but low in the remainder of Unit 1 , increasing only slowly towards its base. A particularly well-sampled region between 85 and 175 meters shows that short-wavelength velocity variations do occur but are less than $0.02 \mathrm{~km} / \mathrm{sec}$ in amplitude. Velocities within Unit 2 are higher, particularly for thin cristobalitic procellanites and cherts found below 415 meters. Densities, less well sampled than velocities, are more variable but have larger measurement errors. In general, they increase with depth in a similar manner, slowly in Unit 1 and more quickly in Unit 2.

Figure 6 shows that part of each profile which extends northeastward from Site 329 with the correlations which have been made. Both profiles show many reflections, down to a rough basement at about $1.3 \mathrm{sec}$ TW on the RC 1606 profile, but, probably for want of source energy, only down to $0.7 \mathrm{sec}$ TW on the Glomar Challenger profile. The upper $0.45 \mathrm{sec}$ of the latter shows the profusion of sharp, clear reflections typical of unconsolidated biogenic ooze sequences; the cause of any particular reflection cannot be found, because the data here are inadequate. For example, a prominent reflection occurs at $0.17 \mathrm{sec}$ in Figure 6, the two-way time to about 132 meters, where a small but sharp reduction in velocity can be seen in Figure 5 . The density data do not map this depth range adequately, however, so that acoustic impedance is not known in similar detail. Also, there is no obvious lithologic change at this depth. Almost all of Unit 1 lies within this zone of sharp reflections, and its lithologic sub- 


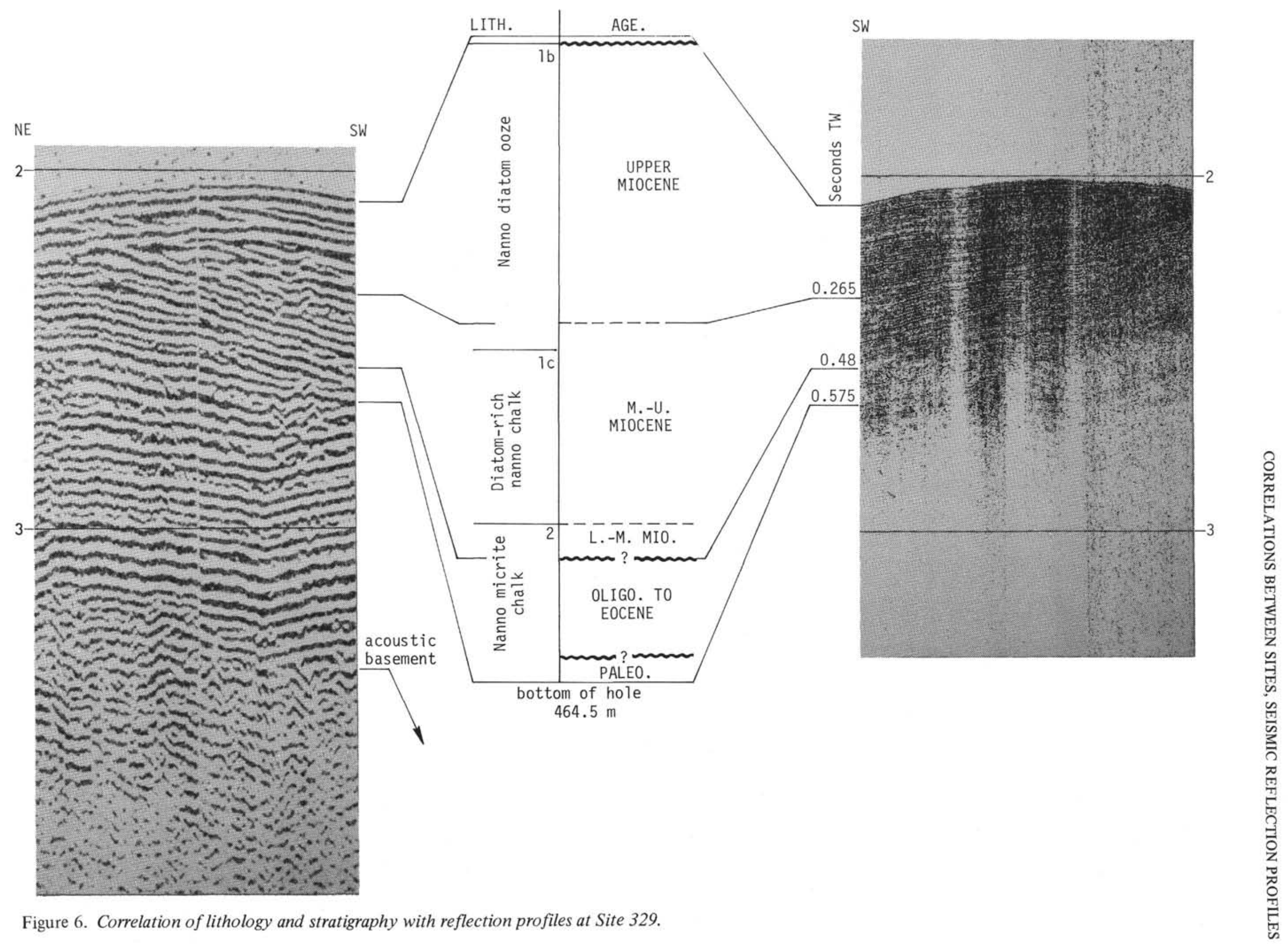




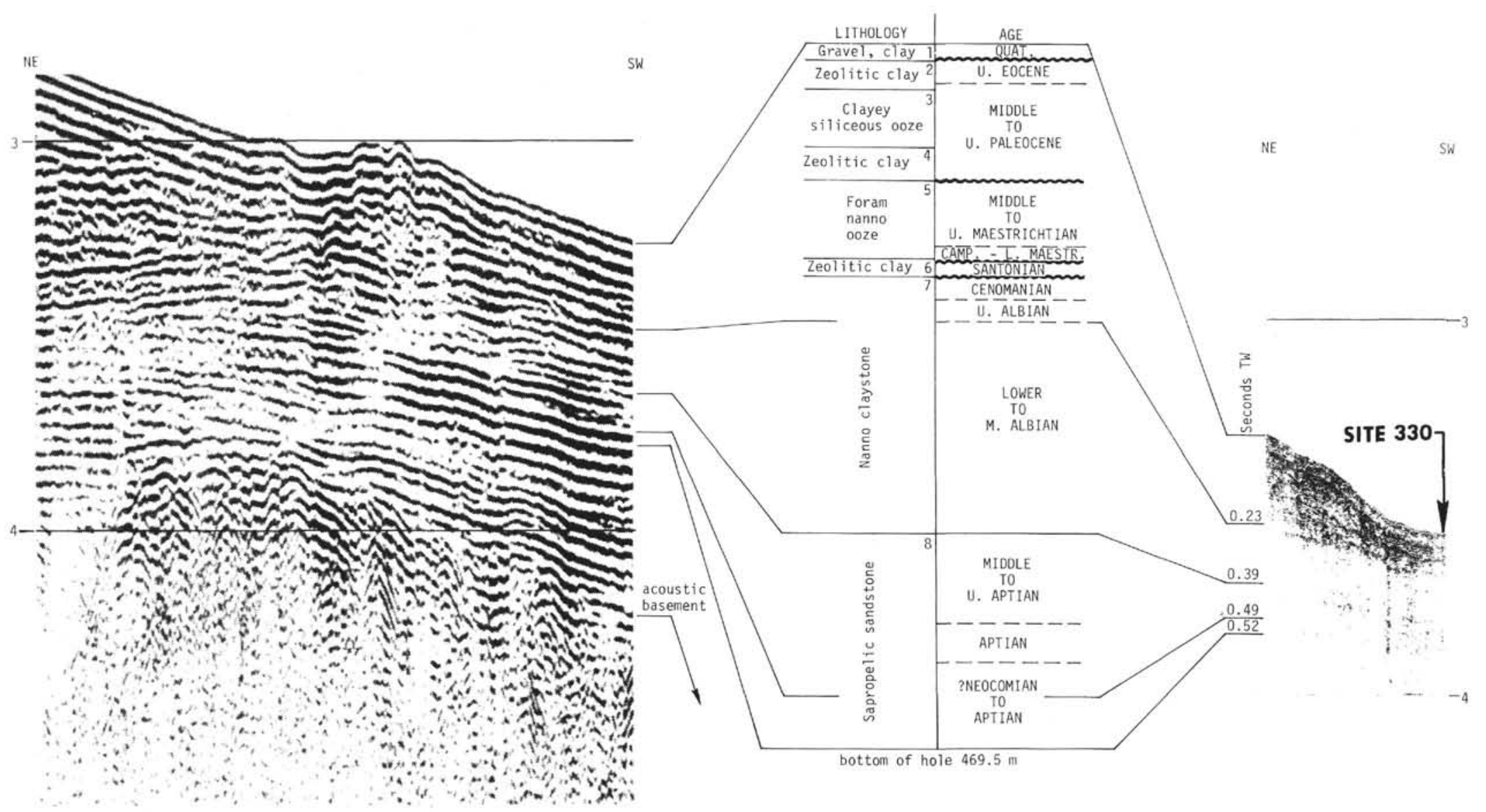

Figure 7. Correlation of lithology and stratigraphy with reflection profiles at Site 327. 
divisions are marked on Figure 6, but none give rise to particularly prominent reflections.

Below $0.45 \mathrm{sec}$ on the Glomar Challenger profile, the reflected energy is more diffuse, which may result purely from a cumulative spatial heterogeneity of the sediments higher in the section. On the other hand, the change occurs towards the base of Unit 1C, where diagenetic effects within the oozes cause a rapid increase in acoustic impedance with depth. If diagenesis is their cause, then these diffuse reflectors should be followed with care, since they will depend in large part upon depth of burial and are therefore potentially diachronous. The pre-middle Miocene boundaries, down to the base of the hole at $0.57 \mathrm{sec}$, all lie within this more diffuse zone (see Table 1).

No such change in character of reflection with depth is seen in the RC 1606 profile of Figure 6. There, the relatively long wavelengths of acoustic energy are insensitive to much of the fine structure of acoustic impedance variation which is displayed in the upper part of the Glomar Challenger profile; the remaining reflections represent the coarser acoustic impedance changes, closer in wavelength to the thickness of the underlying zone of (? diagenetic) acoustic impedance increase.

\section{Site $327\left(50^{\circ} 52.28^{\prime} \mathrm{S}, 4^{\circ} 47.02^{\prime} \mathrm{W}, 2400 \mathrm{~m}\right.$ depth)}

Site 327, the original Falkland Plateau site and the first to be drilled, was chosen on the basis of the profile in Figure 3 to examine particularly the earlier history of sedimentation on the plateau, avoiding the bank of presumed Neogene sediment upslope. Coring at the site was continuous down to 118 meters, then intermittent (typically one in three) to 469.5 meters. Core recovery is $51 \%$ of the cored interval, $28 \%$ of the total depth, and velocity sampling can therefore be considered no more than representative. Few lithologic or time-stratigraphic boundaries lie within cores and the coring gaps provide a corresponding latitude in identifying reflectors.

The top 13.5 meters of core are of Quaternary sand and gravel, the high proportion of ice-rafted terrigenous material giving a higher velocity and density than are found in the underlying 20 meters of late Paleocene to early Eocene zeolitic clay of Unit 2. Units 3 and 4 beneath, respectively, a biogenic siliceous ooze and zeolitic clay of Paleocene age, also have low velocities and densities. Unit 5, below 90 meters, is up to 56 meters of Maestrichtian foram nanno ooze, with a thin chalk crust and some thin micrite and porcellanite bands which give high values, but otherwise having a velocity and density which still are below those of Unit 1. Unit 6 is of Santonian age where sampled between 146 and 156 meters but probably is a condensed section of Cenomanian to Campanian age. Within this and the underlying Unit 7 , a thick zeolite-rich nanno chalk largely of Albian age, velocities become more variable

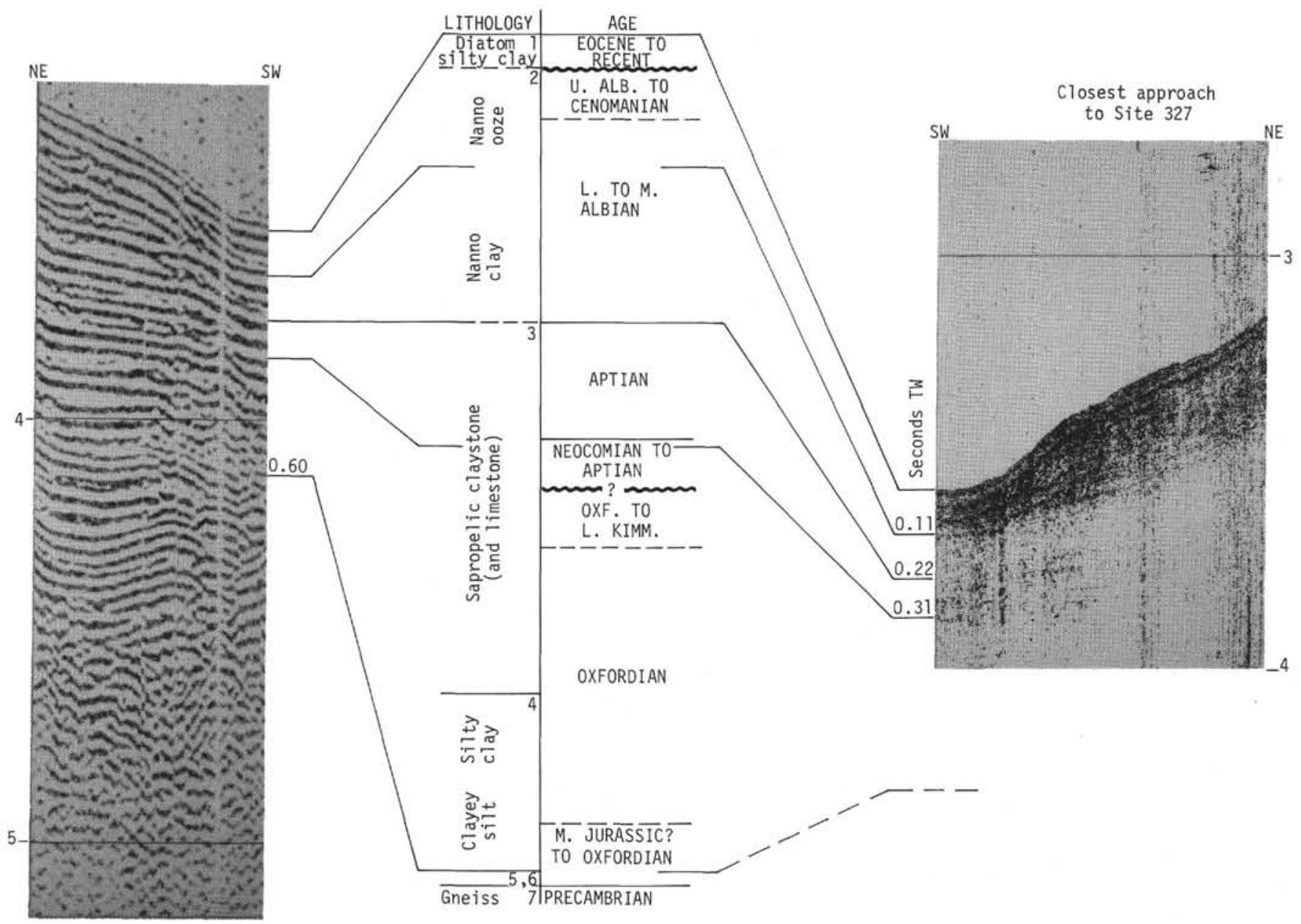

Figure 8. Correlation of lithology and stratigraphy with reflection profiles at Site 330. 
and increase more rapidly with depth. The upper part of Unit 8, from about 336 meters to 440 meters, is a highly indurated Aptian claystone with thin interbeds of micritic limestone. Velocities and densities in the claystone are high, decreasing slightly perhaps down the hole; in the thin limestones they are even higher. A definite velocity inversion occurs below about 440 meters, with a change in lithology to a semi-indurated sapropelic shale in the lower part of Unit 8, to the base of the hole at 469.5 meters. Most of Unit 8 is of Aptian age, so that sedimentation rates within Units 7 and 8 were high.

It is interesting to note that the Paleocene siliceous ooze and clay of Units 3 and 4, found between 33 and 89 meters at Site 327, have a mean measured velocity of $1.53 \mathrm{~km} / \mathrm{sec}$ and density of about $1.4 \mathrm{~g} / \mathrm{cm}^{3}$. At Site 329 , the originally calcareous and siliceous biogenic ooze of the same age occurring below 445 meters has undergone diagenetic alteration to silicified micritic chalk and possesses an average velocity and density each about $50 \%$ higher. This observation underlines the problem stated earlier, of the possibility of diachronous reflectors, and suggests that the depth of burial of this unit at Site 327 has never been much greater than at present.

Depths to the major lithologic and stratigraphic boundaries down the hole, derived from the velocitydepth model of Figure 5, are marked against two sections of reflection profile in Figure 7 and listed in Table 1. One section is that part of the RC 1606 profile which lies directly upslope (northeast) from the site; the other was obtained by Glomar Challenger on passage between Sites 329 and 330 , since the weather was too rough for good data to be obtained both on approaching and on leaving Site 327 itself. This section extends downslope (southwest) from the point of closest approach to Site 327.

Generally, not very much reflected energy is seen on the Glomar Challenger profile, while the RC 1606 profile suffers from a surfeit. A faint reflection at about $0.40 \mathrm{sec}$ TW on the former corresponds to the base of Unit 7 and indicates a depth of 336 meters; some deeper energy, even less obvious, at 0.48 to $0.50 \mathrm{sec}$ TW may represent the velocity inversion within Unit 8 . Several other rather intermittent reflections can be seen in the upper $0.24 \mathrm{sec}$ TW (about $190 \mathrm{~m}$ ) and can be given approximate ages and made use of in correlating between holes. On the RC 1606 profile also, prominent reflections, apparently primary, occur at 0.39 and $0.42 \mathrm{sec}$ TW, corresponding to the top of Unit 8. There is some indication also of a reflection in the vicinity of $0.48 \mathrm{sec}$, but the early part of it is distorted by the later part of the wavetrain of the earlier event. A reflection, apparently primary, occurs also at $0.23 \mathrm{sec}(184 \mathrm{~m})$, as in the Glomar Challenger profile, close to the top of Unit 7. Although other, earlier reflectors are present, the long wavetrain $(0.2 \mathrm{sec})$ of the sea bed reflection prevents any positive identification.

The base of the hole is at $0.52 \mathrm{sec}$ TW; at least a further $0.5 \mathrm{~km}$ of sediment (containing at least one strong reflector) appears to lie between there and acoustic basement at the site.
Site $330\left(50^{\circ} 55.19^{\prime} \mathrm{S}, 4^{\circ} 53.00^{\prime} \mathrm{W}, 262 \mathrm{~m}\right.$ depth $)$

Site 330 lies $9 \mathrm{~km}$ southwest of Site 327 and downslope. Recovery was $43 \%$ of the cored interval, but only $16 \%$ of the total depth of the hole. Since the intention was to examine the lower part of the sedimentary succession on the Falkland Plateau where it was more accessible than at Site 327, the upper part of the hole was particularly poorly sampled. Only four cores were obtained in the upper 300 meters and the uppermost velocity measurement is on a sample from 130 meters. An " $A$ " hole designed to remedy this defect largely failed, providing no samples suitable for measurement because the core bit was obstructed by basement rock from the bottom of the first hole. Some ages were gained from the "A" hole, from mud sticking to the bit for example, so to a certain extent the velocity-depth model can be refined by comparison with the section at Site 327. An uncertainty remains, however, in two-way travel times to all of the deeper interfaces, from coring deficiencies in the upper part of the hole.

By analogy with Sites 327 and 329, the topmost 5 meters of sediment at Site 330 is presumed to consist of ice-rafted Quaternary sand and gravel, with a velocity of $1.75 \mathrm{~km} / \mathrm{sec}$. The next 15 meters is taken as Eocene silty clay, as was found in Core $330 \mathrm{~A}-1$. Albian to Cenomanian nanno clay found below 34 meters (Core $330 \mathrm{~A}-4$ ) is presumed to extend from 20 meters to below the depth where velocity measurements become available, in Cores 330-1 and 2. This unit (Unit 2) is given a slight velocity gradient to account for compaction and diagenesis near its base, but has a lower velocity range than its deeper stratigraphic equivalent, the nanno claystone of Unit 7 at Site 327.

Below this unit the coring interval remains large, and the evidence of the next two cores must again be supplemented by reference to Site 327 . Cores 3 and 4 are of the same age as the upper and lower parts of Unit 8 of Site 327, respectively, and are lithologically similar. Velocities measured on these cores support the notion that a high-velocity layer above a distinct velocity inversion occurs here, as at Site 327. This layer is thinner at Site 330, being confined between Cores 2 and 4, and has been given a slightly lower velocity $(2.1 \mathrm{~km} / \mathrm{sec})$ in accord with the comparison made above of the overlying beds at both sites.

Below 300 meters, sampling is slightly more frequent. ?Neocomian to Aptian sapropelic claystone in Core 4 gives way to Oxfordian to lower Kimmeridgian sapropelic claystone in Cores 5 to 10 , within a 19 meter coring gap and without apparent lithologic change. Velocities at the top of this sequence are lower than at Site 327 , but increase down the unit to a similar value. For this and the underlying Unit 4, a sand, silt, and clay sequence of ?Middle Jurassic to Oxfordian age, the velocity-depth model is biased slightly high to take account of the contribution of rare, thin, high-velocity limestones. Below 540 meters, a thin sequence of sands, silts, and lignite probably representing a basal marine transgression possesses a rather higher velocity, and an acoustic basement of calcitized granite gneiss is found at 547 meters. 
Densities increase steadily down the hole, from about $1.62 \mathrm{~g} / \mathrm{cm}^{3}$ at 130 meters to $2.06 \mathrm{~g} / \mathrm{cm}^{3}$ directly above basement, and without a significant excursion in Core 3 to match the high velocities. The acoustic impedance variation therefore matches closely that of velocity. Prominent reflectors might be expected at the top and base of the upper part of Unit 3 and directly above basement.

The Glomar Challenger profile in Figure 8 is identical to that in Figure 7; Sites 327 and 330 are only $9 \mathrm{~km}$ apart and the position of the former is marked. The section of RC 1606 profile used in Figure 8 also extends upslope from Site 330, but not as far as Site 327. The uppermost $0.11 \mathrm{sec}$ TW of the Glomar Challenger profile at Site 330 contains the reflectors which at Site 327 occupied the upper $0.23 \mathrm{sec}$ TW. This includes a reflector at $0.11 \mathrm{sec}$ which lies within the Albian to Cenomanian clays of Unit 2 as did its equivalent within Unit 7 at Site 327, but which cannot otherwise be accounted for. The profile shows that the latest Cretaceous and Paleogene section at Site 327 is truncated downslope, in agreement with the somewhat tentative findings from the " $A$ " hole at Site 330. Deeper in the section, a reflector at $0.23 \mathrm{sec}$ TW is continuous with that at $0.39 \mathrm{sec}$ at Site 327, where it corresponds to the top of the high-velocity Aptian claystone. At Site $330,0.23 \mathrm{sec}$ is equivalent to about 186 meters, directly below Core 2. Similarly, the faint 0.48 and $0.50 \mathrm{sec}$ reflections at Site 327, probably corresponding to the velocity inversion at the base of this layer, continue to $0.31 \mathrm{sec}$ TW at Site 330 . The equivalent depth is 270 meters, directly above Core 4 and therefore in agreement with the lithology. These depths have been incorporated into the velocity-depth model in Figure 5.

As usual, there is much interference from other reflections on the RC 1606 profile in Figure 8. Almost certainly there is a strong primary reflector at $0.11 \mathrm{sec}$ TW, despite interference from the bubble-pulse of the sea-bed reflection. The wavetrain of this reflector in turn obscures the record in the vicinity of $0.23 \mathrm{sec}$, but a strong primary event can be seen at $0.31 \mathrm{sec}$ TW.

The dips of these reflectors steepen slightly towards Site 330 on both profiles, an illusion of the replacement of higher velocity sediment with lower velocity water above them in the section as they approach the sea bed downslope. Additionally, the RC 1606 profile shows a further apparent half-wavelength depression of these reflections in the vicinity of Site 330 which is not seen on the Glomar Challenger profile. This too may be illusory, the result of a phase change or intraformational multiple reflection in the uppermost layers. A likely cause is a small pond of reworked younger sediments lying in a depression eroded into older, higher velocity material. It is probable that the deeper horizons are more planar than they appear, and that the Eocene silty clay found (disturbed by the coring process) in Core $330 \mathrm{~A}-1$ is part of a younger redeposited sequence, restricted in occurrence (on this profile) to the environs of Site 330 .

The apparent hiatus below Core 330-4 lies between 0.33 and $0.35 \mathrm{sec}$ TW. No obvious reflector is seen at these depths on Glomar Challenger profiles, either approaching or leaving Site 330; energy from the $0.31 \mathrm{sec}$ reflection obscures that part of the RC 1606 record but, as would be expected from the lack of variation in measured acoustic impedances, there is no evidence of a particularly strong reflector.

The next strong packet of reflected energy on the RC 1606 profile at Site 330 starts at $0.60 \mathrm{sec}$ TW, equivalent to 540 meters, the depth to the basal, ? subaerial sandstone and only 7 meters above metamorphic basement. The reflector is subhorizontal and probably does represent the basal sandstone, but, only a short distance to either side of the site, other deeper and also apparently sedimentary reflectors can be seen; reflections more typical of basement only show strongly 0.1 or 0.2 $\mathrm{sec}$ TW beneath. However, the reflection at $0.60 \mathrm{sec}$ is not precisely planar, turning down at either side of the site in a manner typical of a plane reflector with a gap in it, such as a buried river channel or graben. In this particular case the plane reflector is probably a basal sand or conglomerate sequence, which fails to give strong reflections where it is thinned or replaced entirely by basement. The crystalline basement itself does not give a strong reflection at that depth, despite the high impedance contrast, being at the site a series of rugged, isolated peaks.

\section{CORRELATION BETWEEN SITES}

In the previous section, it was possible either to identify specific reflectors on the profiles at each site, or to place a biostratigraphic boundary within a series of reflectors, each of which was probably approximately synchronous. The reflection profiles can now be used to trace these identifications between sites and beyond. The reliability of the time section so produced depends upon the accuracy of identification at the site, considered above, the ease with which reflectors can be traced between sites, and the extent to which they retain their identity. The complementary nature of the two profiles has also been pointed out; this section considers first the Glomar Challenger profile, to obtain good resolution within the upper layers, applies the results to the RC 1606 profile and finally extends the analysis to deeper horizons using the superior penetration of the latter.

\section{Glomar Challenger Reflection Profile}

The profile shown in Figure 4 is presented as an interpreted time section in Figure 9. As the track chart of Figure 2 shows, the profile includes all three sites and extends for about $90 \mathrm{~km}$ northwestward, but only for 8 $\mathrm{km}$ to the southwest. Vertical exaggeration within Figure 9 varies between 26 and 40 to 1 in water, depending upon ship speed, and is less in the sediments in proportion to their higher acoustic velocity. The thin lines within the section are acoustic reflectors, unidentified but considered generally to be isochronous. The thicker lines are stratigraphic boundaries, usually but not necessarily acoustic reflectors themselves.

The late and middle Miocene sediments contain many sharp reflectors which can be followed with confidence to where they crop out at the sea bed to both sides of Site 329. The sediments form a restricted bank along the line of section, and there are no signs of significant post-Miocene deposition. The reflectors 


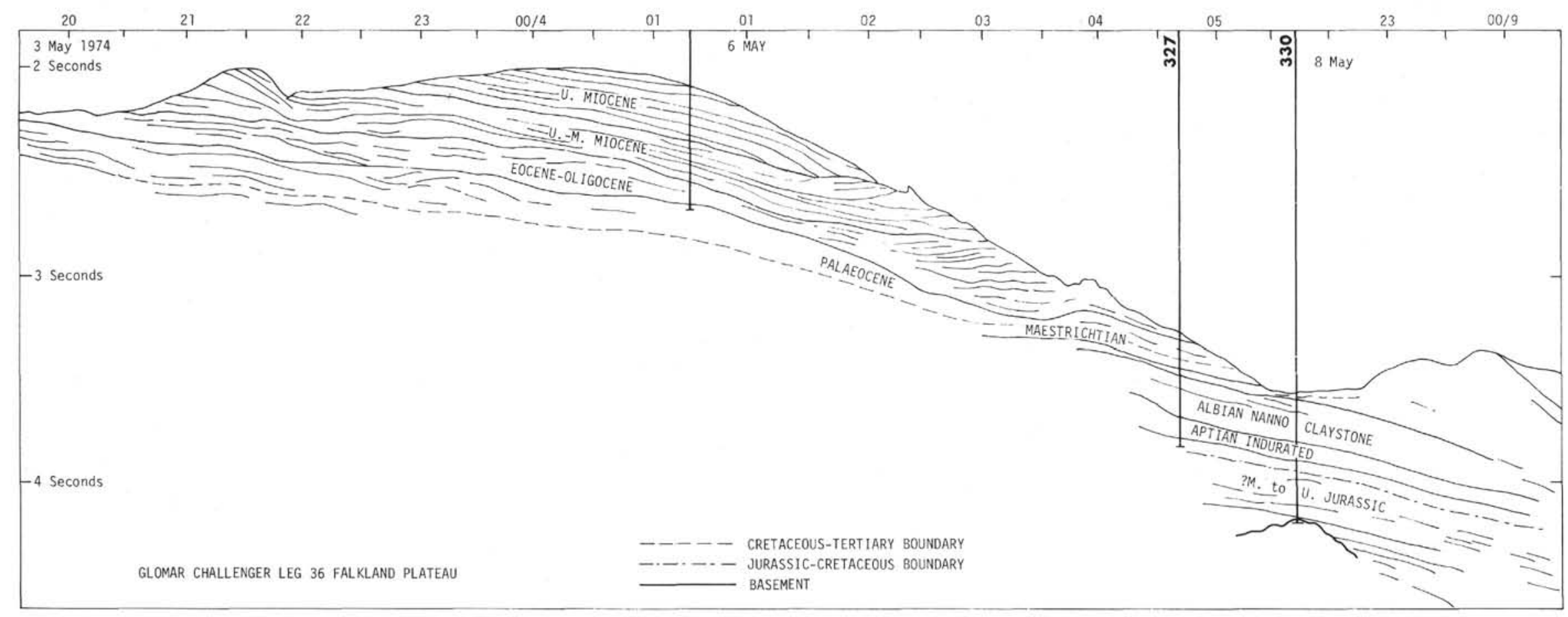

Figure 9. Interpreted time section from Glomar Challenger reflection profile, eastern Falkland Plateau. 
become more diffuse and less continuous with increasing age, leading to a slight drop in the confidence with which the base of the Eocene/Oligocene layers, and the more irregular reflectors within them, can be followed. The uncertainty increases again with the Paleocene, the base of which lies below the base of the hole at Site 329 and is therefore entirely speculative. Some conclusions, however, are clear. If present, lower Miocene sediments occur at Site 329 within a 19-meter coring gap, and appear nowhere along the section to become much thicker (except conceivably beneath the small bank at the eastern end). Thus, really rapid sedimentation along this section is confined to the late and middle Miocene and the hiatus at their base is representative of a more widespread unconformity. Similar hiatuses may occur within the Eocene/Oligocene sequence at the site, since microfossil zonation is difficult and further coring gaps occur; indeed, away from the site in both directions these sediments thicken, particularly downslope, although only a very thin lower Eocene sequence is seen at Site 327. The thin Eocene layer inferred at Site 330 from the evidence of one short, very disturbed core (330A-1) may represent later redeposition of sediments eroded from oozes of that age exposed upslope, as discussed previously. The presence of such a thin pod of unconsolidated sediments, confined to the topographic trough in the vicinity of Site 330 , could explain some misleading features of the RC 1606 reflection profile directly beneath the pod, at the site.

In the vicinity of Sites 327 and 330, the penetration of the Glomar Challenger profile extends down into the Mesozoic, because these older beds come closer to the surface. Indeed Maestrichtian and even older beds apparently crop out between Sites 327 and 330 . The quality and continuity of reflections here are not as favorable as near Site 329, but, because the two sites are close, are adequate for confident correlation between them. As mentioned above, the Paleocene appears to thicken upslope, a consequence possibly of the proximity of the carbonate compensation depth (CCD) to the lower sites at this time as shown by Wise and Wind (this volume). On this profile (Figure 9) none of the deeper horizons give visible reflections upslope from Site 327, although it seems likely that, much further east (see Figure 4), the Mesozoic sediments may again crop out at the sea bed.

Beneath the Maestrichtian nanno ooze lies a maximum of 12 meters (at Site 327), largely of clays and representing sedimentation over a $20 \mathrm{~m} . \mathrm{y}$. period, above an Albian nanno clay or claystone. This depth range is poorly sampled at Site 327 and virtually unsampled at Site 330, but the reflectors in the intervening region of the profile are reasonably well defined.

The Maestrichtian and Albian lithologies at Site 327 extend into the Campanian and Cenomanian, respectively, but probably not very far if the high sedimentation rates are maintained. The small thickness of the intervening "Late Cretaceous condensed section" could in theory result from erosion, rather than slow deposition. Reflectors in the vicinity are essentially smooth and near parallel, however, suggesting quieter conditions of slow deposition; if anything, the condensed section thickens slightly downslope. An exception occurs over a short distance to either side of Site 330, where the condensed section apparently crops out and probably has been partly eroded. Such erosion would be much younger, however, since upslope it appears to affect also the overlying Cenozoic sediments.

Although horizons older than Albian produce reflections on the Glomar Challenger profile (there is even an indication of basement southwest of Site 330), the balance of usefulness swings towards the RC 1606 profile at about this age, and the remainder of the Glomar Challenger profile will therefore be described in parenthesis. The Jurassic-Cretaceous boundary is not a reflector, but its approximate location is shown in Figure 9.

\section{Robert Conrad (RC 1606) Reflection Profile}

The RC 1606 profile of Figure 2 is presented in Figure 10 as an interpreted time section. The section includes all three sites and in addition extends upslope (northeastward) for about $12 \mathrm{~km}$ (to the course alteration, see Figure 2) and to the southwest and south for $75 \mathrm{~km}$. As in Figure 9, thin lines denote subbottom reflectors which can be followed with reasonable confidence, and thick lines are identified stratigraphic or lithologic boundaries, which usually, but not necessarily, coincide with reflectors. Additionally, thick lines are used in the righthand side of Figure 10, where no aids to identification are found, to distinguish the more prominent reflectors. Vertical exaggeration is 19 to 1 in water, less in the sediments.

As previously stated, the RC 1606 profile penetrates to a rough acoustic basement along virtually the entire length interpreted in Figure 10. The main difficulty in identifying reflectors and following them away from and between sites lies in mutual interference and poor resolution, resulting from the low dominant frequency and long wayetrain of the acoustic source. Where possible, therefore, the disposition of reflectors within the Glomar Challenger profile has been used to help trace reflectors in the RC 1606 profile. The lower frequencies in the latter lead to fewer prominent reflectors, not necessarily at the same depths as those in Figure 9. Usually, however, an RC 1606 reflector coincides with one of the Glomar Challenger reflectors, and there are no cases of unambiguous reflectors on both profiles behaving incompatibly.

As on the Glomar Challenger profile (Figure 10), the Miocene sediments form a restricted bank, the EoceneOligocene sediments thicken downslope, and all Cenozoic reflectors crop out at the sea bed between Sites 329 and 330 . The continuation upslope of the reflector representing the base of the Paleocene is less certain, since the Cretaceous is not penetrated at Site 329 ; extension of the underlying layers is even less certain, since no assistance with their location is available from the Glomar Challenger profile upslope from Site 327. The reflector within the Albian clay/claystone $(0.23 \mathrm{sec}$, Unit 7 at Site 327), and the top and base of the more indurated Aptian claystone can be followed with confidence between Sites 330 and 327, but not for 


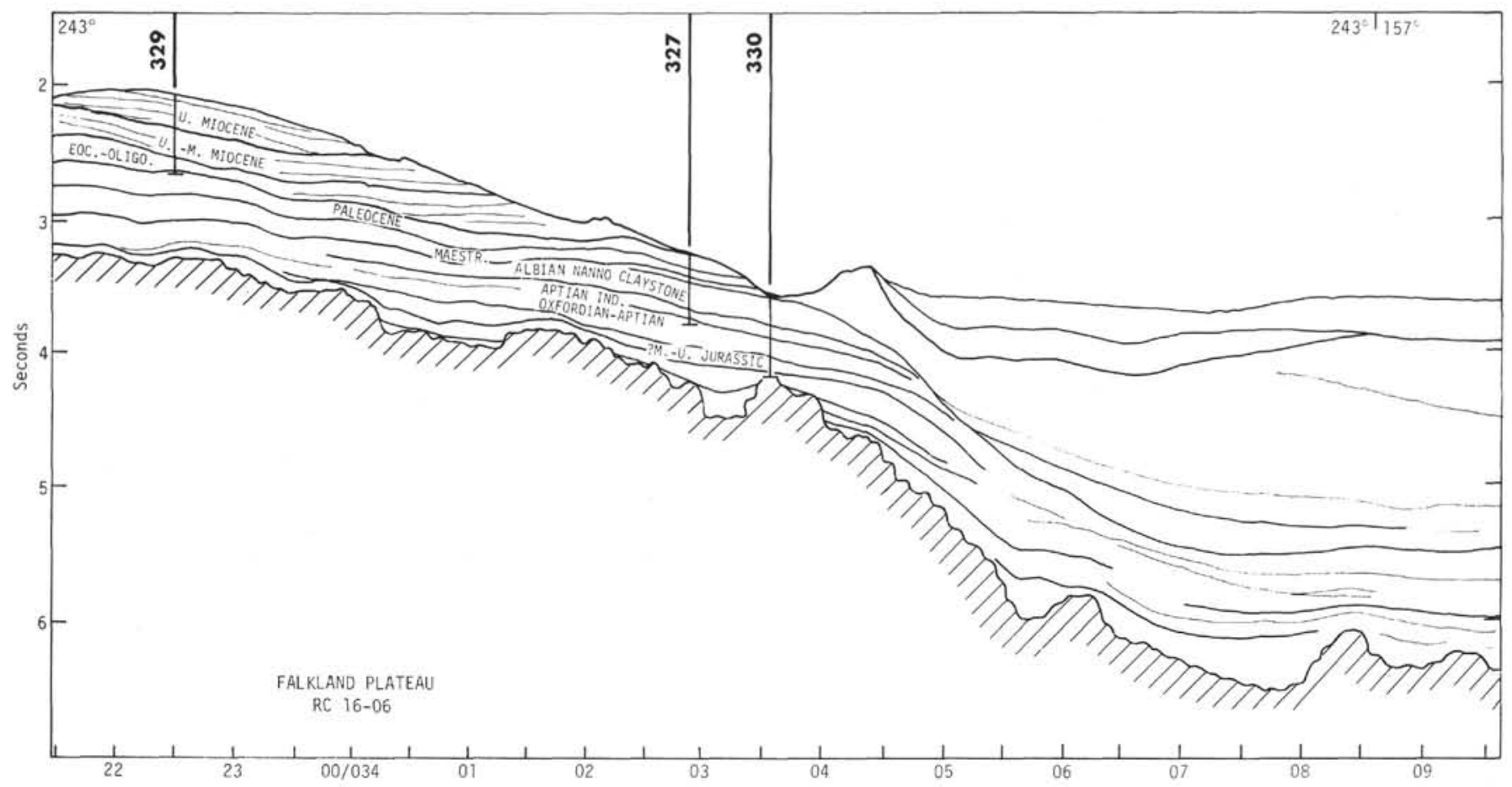

Figure 10. Interpreted time section from RC 1606 reflection profile, eastern Falkland Plateau.

very far upslope. The approximate position of the boundary between Units 3 and 4 (Site 330) can be traced only for about the same distance, but the reflection identified with the basal sandstone at Site 330 is quite strong and can be followed with confidence to the northeastern end of Figure 10. It must be borne in mind, however, that these two interfaces are lithologic changes consequent upon a marine transgression, and may therefore change in age or facies laterally. Although all Mesozoic reflectors cannot be followed with complete confidence, it is noticeable that the preMaestrichtian sedimentary sequence thins considerably upslope; where they are defined, some thinning can be seen of all of the constituent layers, and at least the Jurassic sediments appear to onlap the basement.

The reasons why the basal sandstone reflection dips downwards towards Site 330 on either side, and the metamorphic basement gives a strong reflection only lower in the section, were discussed earlier. It is sufficient to say here that the reflection profile is consistent with the presence of a planar "basal sandstone" reflector, overlying a sharp and isolated basement high at shallow depth directly at Site 330. Away from the site, basement lies deeper and the planar reflector may well change its lithology; deeper sedimentary horizons appear in the record.

Downslope from the drill sites, the reflection profile changes completely: the total thickness of sediments increases from about $1 \mathrm{sec}$ TW to more than $2 \mathrm{sec}$ TW and tracing identified reflectors becomes an entirely speculative exercise. It is more appropriately discussed later, as part of a consideration of the extent to which the interpretation of the reflection profiles supports and extends the regional geologic history deduced from the cores.

\section{REFLECTION PROFILES AND THE GEOLOGICAL HISTORY}

In considering how the interpreted time sections of Figures 9 and 10 bear upon the geologic history of the eastern Falkland Plateau, it is useful to start by examining again the relationship of the sites and profiles to the eastern plateau as a whole. The three sites all lie on the southwestern "nose" of the isolated eastern elevated part of the plateau (Maurice Ewing Bank, Figure 1). Figures 4 and 9 extend for some distance northeastward from the sites, along the crest of the elevated block; Figures 3 and 10 pass southwest and south from the sites, off the elevated block down to the eastern end of the deeper, central part of the plateau, which extends westward almost to the Falkland Islands themselves. A major interpretational problem is the extent to which the reflection profiles, in the absence of additional information, can be regarded as dip sections for any particular subbottom horizon. It must be borne in mind, therefore, that there may be a component of dip, onlap, or other unconformity which is perpendicular to the section and therefore undetectable. Since to some extent it reflects gross crustal structure, the bathymetry provides a preliminary guide to the direction of dip. On this basis it would appear that the more southwesterly parts of the profiles, downslope from Site 329, may well be approximate dip sections; this is not equally obvious for the northeastern parts of the profiles, which run along the ridge crest.

The post-Paleozoic geological history of the Falkland Plateau region, as revealed by the cores obtained at Sites 327,329 , and 330 can be summarized as follows (for more detail, see Site Report chapters and Sedimentologic and Paleontologic chapters, this volume): 
1) A ?Mid-Jurassic to Oxfordian marine transgression at Site 330 was succeeded by deposition of about 120 meters of terrigenous sediments, in which grain size, terrigenous fraction, and bioturbation all increase downwards.

2) A period of restricted circulation followed, extending from Oxfordian to Aptian, in which about 200 meters of organic-rich claystone with rare thin limestone interbeds were deposited. The upper part of this unit is the more indurated and bioturbation occurs only very near to the base and top. A considerable hiatus, between Oxfordian and Aptian, probably occurs within this unit; during this period not even the very fine grained terrigenous detritus which apparently forms the bulk of the major lithology was deposited. In about the middle of the apparent hiatus, the South Atlantic and possibly the other intra-Gondwanaland oceans started to open (South Atlantic at about $127 \mathrm{~m} . \mathrm{y}$.-Larson and Ladd, 1973), and a period of uplift may have interrupted the otherwise slow and steady subsidence. There is only the faintest trace in the cores, in the form of reworked Kimmeridgian palynomorphs within the overlying ?Neocomian to Aptian claystones, of elevation to wavebase or above, at Site 330 or upslope.

3) Circulation had improved by the Albian, during which stage about 150 meters of a nanno clay or claystone was deposited and further subsidence took place. Paleontologic depth indicators suggest a complex history of uplift and subsidence during the Late Cretaceous and Neogene which cannot be explained in terms of what is known of the regional tectonics; if these apparent excursions can be accounted for alternatively by $C C D$ and temperature variations, a more simple and attractive tectonic history can be adopted, of exponentially slowing subsidence akin to that of oceanic crust. This suggests that the plateau had sunk to within 500 meters of its present depth by the Maestrichtian. The Late Cretaceous condensed section, at most 12 meters thick, is then explained by the passage of corrosive bottom currents across the central part of the plateau between the Argentine Basin and Weddell Sea, but the direction and cause of such currents are unknown.

4) Deposition of calcareous oozes began again during the late Campanian and continued with short hiatuses through the Paleogene into the Miocene. No sediments of any thickness younger than late Miocene are present at any of the sites. Deposition since the Maestrichtian is considered to have been under conditions of increasingly vigorous circulation, almost entirely above the CCD and, at least during the middle and late Miocene, very rapid as a result of increased biological productivity.

There is no major point in the above summary which is contradicted by the evidence of the reflection profiles; in general, they support, refine, and extend the information obtained from the cores.

1) The Jurassic marine transgression at Site 330 is revealed as part of a steady process of subsidence. The 250 meters or so of Jurassic sediment at the site appear to onlap the basement reflector upslope. Site 330 was drilled on an isolated basement high and undeformed sediments older than those cored, probably nonmarine, can be seen in adjacent hollows. Downslope these older sediments, presumably marine here, appear to thicken towards the floor of a basin. The lack of obvious major faulting in these and the overlying sediments indicates that the basin was in existence in Mid-Jurassic times, to the south of the Site 330 shoreline.

Along the line of section, it can be seen that subsequent sedimentation has partly, but not entirely, obscured the Mid-Jurassic distinction between shelf and basin. It is reasonable to assume, therefore, that an approximate estimate of the extent of shelf and basin can be gained from the bathymetry. On this basis (see Figure 1 and the bathymetric chart in the back pocket of this volume), the basin probably extends over most of the central, deeper parts of the Falkland Plateau-a basin province-and the elevated eastern block, with the region around the Falkland Islands themselves, forms a complementary shelf province. This dichotomy has existed since at least the Mid-Jurassic. Seismic refraction lines shot in other parts of this basin province (by Ewing et al., 1971) suggest that, beneath similar thicknesses of sediment, it has a continental rather than oceanic crustal structure. The fact that depth to basement at present is too shallow for normal oceanic crust of this age (Sclater et al., 1971) supports this suggestion, as does the offset of only $2 \mathrm{~km}$ or so between acoustic basement in the basin (in Figure 10) and in the vicinity of Sites 327 and 330 on the shelf. That is to say when basement at Site 330 was at sea level, basement in the basin was rather too shallow to be even recently formed normal oceanic crust.

The basal sediment reflector at Site 330 can be traced downslope (with some uncertainty), to lie between 0.4 and $0.7 \mathrm{sec}$ TW ( 0.5 to $0.9 \mathrm{~km}$ ?) above basement in the basin. Thus, the Mid-Jurassic basin contained about $1.5 \mathrm{~km}$ of water, and directly downslope from the site there existed in sedimentary terms a continental shelf and slope (even though the basin floor was not of oceanic crust). The shelf was apparently being built out by the terrigenous sediments of Unit 4 (Site 330) and those beneath, and the basin would presumably have been receiving finer grained terrigenous sediments. However, the possibility arises again of the dominant factors, in this case, other sediment sources, lying off the line of the profiles. The present bathymetry shows no other likely sediment source nearby, but of course the Mid-Jurassic paleogeography was very different. Southern Africa, elevated, lay to the north and probably was a source of terrigenous sediment to the entire plateau; the Falkland Islands region and the Maurice Ewing Bank itself would be lesser sources. To the south at present lie the Falkland Trough and north Scotia Ridge. Although the older sediments appear to continue southwards beneath the trough (Figure 3 ), it is not known if this most southerly region was a topographic depression in the Mid-Jurassic. Similarly, the present form of the north Scotia Ridge is probably a Cenozoic development, consequent upon the opening of the Scotia Sea; it seems likely, however, that the Falkland Plateau in the Mid-Jurassic was an intraGondwanaland basin, representing an early stage of breakup, so that an additional southerly sediment source, continental or a marginal orogenic belt, was a distinct possibility. 
2) Restricted circulation is indicated by sediments of Oxfordian to Aptian age at Sites 327 and 330 (see Thompson, this volume). These comprise very fine grained terrigenous debris, and within them apparently occurs either a hiatus or condensed section without lithologic change and extending from the Kimmeridgian through the Barremian. These sediments also appear to build out the margin downslope from Site 330 , but in no way present a barrier to circulation within the basin. It appears possible, even likely, therefore, because of the "exposed" situation of Site 330 at the time, that circulation was restricted within the entire basin province. This is consistent with the view that the Falkland Plateau was still at that time an intracontinental basin, probably closed to the Pacific, and that the other intra-Gondwanaland oceans did not start to open before the South Atlantic. The lithology of the Oxfordian to Aptian sediments indicates that terrigenous sediment sources at the time were distant; southern Africa still lay to the north, but, as explained by Thompson (this volume), a narrow, downfaulted trough between there and the plateau could easily have formed during the early stages of breakup and acted as a sediment trap. Sources on the eastern plateau itself, small and partly submerged, would have been relatively minor. Such a hypothesis, of starvation, is more consistent with the disposition of acoustic reflectors near and upslope from Site 330 than any postulate of uplift and subaerial erosion to explain the apparent hiatus. As for the restriction, the presence of some kind of barrier to circulation to the south is an essential requirement, although the occasional thin limestone beds found in these sediments suggest intermittent access to more oxygenated water, perhaps from the south or west.

It remains virtually impossible to trace sediments of this age from the shelf province into the basin; we may speculate that the strong basin reflector at about $5.5 \mathrm{sec}$ TW represents the top of this equivalent layer; unless other terrigenous sources contribute, only a thin equivalent layer would be expected.

The much more indurated, upper part of this unit, of Aptian age, is of a fairly uniform thickness, as far as it can be traced upslope. The base of this layer can apparently be followed to the northeastern end of Figure 10, beyond Site 329. It seems at least possible, however, that the character of the reflector will there be quite different. The cause of the greater degree of induration is unknown; it may be a diachronous effect. The Kimmeridgian-Neocomian hiatus may well become broader upslope; the possibility arises, therefore, that these two horizons will merge upslope, to produce the reflector seen.

3) Circulation improved during deposition of the $\mathrm{Al}$ bian nanno claystone (Unit 7 of Site 327, Unit 2 of Site 330 ), probably because of the creation of a deep water connection east of the Falkland Plateau between the widening South Atlantic and Indian oceans. The claystone thins both up- and downslope from the sites, the first sign, perhaps, of entirely pelagic, currentguided deposition as the eastern elevated block became an isolated bank. The overlying unit is 12 meters (maximum) of Upper Cretaceous condensed section of pelagic zeolitic clays at Site 327, indicating subsidence below the CCD. The thinning downslope of the underlying Albian nanno claystone therefore may also reflect the onset of this effect. The upper boundary of this unit is somewhat irregular upslope, which may indicate submarine erosion in some places. Whatever the balance of causes, however, a change in the relationship of the shelf and basin provinces is apparent at this time. The Albian and later sediments no longer appear to build out the shelf, as would sediments from a landward (upslope) source, but rather to degrade it. Such a process demands rather more than merely steady pelagic deposition, which would tend largely to preserve the margin. An agent of imbalance is necessary, such as an additional terrigenous source feeding the basin, locally high productivity, or redistribution of sediments by bottom currents. In the Late Cretaceous, bottom currents probably were not strong, but there is much evidence that they became so later. The rising Cordillera of southern Chile or their more easterly extension become a likely source of terrigenous sediment, as they were (of lutite) at Site 328, although it is not known if in the Late Cretaceous the Falkland Trough and north Scotia Ridge were in place. To the south may have lain open ocean, deeper than the plateau, but there is no sign of an associated high productivity of biogenic oozes in the drill holes. Thus, if the thick sediments in the basin province are of Late Cretaceous (pre-Maestrichtian) age, they are probably terrigenous.

4) Maestrichtian and Paleogene calcareous biogenic oozes at Sites 327 and 329 are signs of a fall in the CCD as suggested by paleontologic and sedimentologic studies (this volume), since the known regional geology provides no cause for further vertical tectonic movement of the eastern plateau. That both of these units contain thin interbedded clays at Site 327 and both thicken upslope support this interpretation and indicate more than one cycle of CCD movement; whether these are worldwide or largely local events, however, is unknown.

The Paleocene and overlying Eocene-Oligocene oozes contain many discontinuous and irregular reflections, which indicate deposition under conditions of fairly strong bottom currents. The late and middle Miocene oozes form a restricted bank along the line of section and their much higher sedimentation rates suggest either proportionately higher productivity and/or some kind of localization by eddying of bottom currents. Their extent off section is unknown.

Beneath up to 5 meters of Quaternary ice-rafted terrigenous sand and gravel, sediments of all ages from pre-Maestrichtian (but post-Aptian) to late Miocene crop out at the sea bed between Sites 329 and 330. The same sediments appear to crop out also to the northeast, but identification is less certain. The shape of the sea bed relative to subbottom reflectors strongly suggests not merely nondeposition but vigorous erosion. Various depth indicators within the cored sediments establish beyond doubt that such erosion was entirely submarine.

Two discontinuities in the sea bed between Sites 329 and 327 are revealed as the results of bedding-related differential erosion and it seems almost certain that the 
much larger anomalous elevation southwest of Site 330 is of a similar nature. A likely corollary is that the southwestern margin of this feature suffered erosion at the same time as the northeastern margin, but the effects have been made less obvious by subsequent deposition. That is to say, the deeper of the two reflectors to the southwest, lying between 0.3 and $0.5 \mathrm{sec}$ TW subbottom, is probably a fairly young erosion surface, and the overlying sediment is partly redeposited material which was derived by submarine erosion from other parts of the plateau to the west.

The reflection profiles provide a little information about the age of this period of erosion. As mentioned above, even the Paleocene oozes in the vicinity of the sites show to some extent the type of discontinuous, undulating reflectors which suggest a degree of penecontemporaneous reworking during deposition; these effects are much more pronounced in the EoceneOligocene sediments, the total thickness of which also varies markedly along the section. Miocene sediments contain reworked older microfossils and are disposed in a restricted bank, and there has been no significant post-Miocene deposition at or near the site. A tenable general hypothesis, therefore, on the basis of this evidence, would be that bottom currents have increased steadily through the Cenozoic and are now too strong for the deposition of biogenic oozes on the bank, at least along the line of section. The observed erosion would then be largely a post-Miocene phenomenon.

There are, however, some discontinuities superimposed upon this generalized history of Cenozoic sedimentation, which may be related to singular tectonic or climatic events. The greatest change observed at the sites probably occurs at the base of the middle to upper Miocene oozes at Site 329. Sedimentation rates increase fivefold across this boundary, and the overlying sediments contain reworked Oligocene microfossils. A hiatus at that depth $(362-388 \mathrm{~m})$ is inferred at the site, extending across the early Miocene and much of the late Oligocene, and Figure 9 suggests that this may reflect a more general unconformity along the line of section. A hiatus extending over the same period was found in the Malvinas Outer Basin at Site 328.

This sedimentary discontinuity corresponds reasonably well with a tectonic event. The present regime of very strong bottom currents extends over most of the Falkland Plateau, both deep and shallow, over the north Scotia Ridge and Falkland Trough, and the northern Scotia Sea; it results from the eastward movement of water at all levels through the funnel of Drake Passage. The opening of Drake Passage is certainly a Cenozoic event, but an unambiguous magnetic anomaly dating for the new ocean floor formed as the Antarctic Peninsula separated southeastward from southern South America has not yet been achieved (Barker, 1970). Site 326 was intended to assist this dating process, but unfortunately failed, and the only available indicator is the depth of ocean floor at the margins, which suggests that separation started between 20 and 30 m.y. ago (Barker, in press; Sclater et al., 1971). There is thus an approximate correspondence between this initial opening and the Oligocene-Miocene unconformity at Site 329.
However, there are many other powerful influences, some consequences of the Drake Passage opening, but all serving to complicate the problem. For example, the opening allowed the establishment of a circumpolar current system which, interacting with the present north-south climatic gradient, produces a migrating zone of high biological productivity at the Antarctic Divergence. The present glaciation, at one end of this climatic gradient, has been in existence for about the same length of time (about 25 m.y.; see Hayes and Frakes, 1975) as Drake Passage. Again, following the Drake Passage opening, the north Scotia Ridge and South Sandwich Island Arc would have been formed and have migrated eastward, providing an everchanging series of gaps through which the Drake Passage water could migrate northeastward over the plateau, and varying also the influence of Weddell Sea bottom water, itself seemingly a glacial phenomenon (Brennecke, 1921; Gill, 1973). Thus, it is not unexpected that, while both core samples and reflection profiles provide a geologic history which is completely consistent with an Oligocene or early Miocene opening for Drake Passage, neither is capable of demonstrating the occurrence of only a single, fairly abrupt increase in current strength, or of refining further the age of opening.

The nature of the thick pile of sediments in the basin province, on the right side of Figure 10, can be considered further. It has already been suggested that the Aptian-Albian boundary may lie at about $5.5 \mathrm{sec}$ and that some of the overlying sediments may be of finegrained terrigenous debris transported eastward along the plateau from sources in the rising Cordillera of southern Chile. Also, the small elevation southwest of Site 330 has been interpreted as an erosional feature. Both reflection profiles show the top of the Albian nanno claystone dipping southwestward beneath this feature, but only the Glomar Challenger profile shows very faint and discontinuous reflections above and approximately conformable with that horizon, within the elevation. This evidence suggests that the younger sediments within the basin were continuous with those of the shelf province, simply thickening downslope. A Late Cretaceous condensed section comprising only 12 meters of clay overlies the Albian sediments at Site 327, so that a thick equivalent section in the basin would have to be a ponded terrigenous deposit, probably of turbidite origin. A much more likely situation, therefore, is that the bulk of basin sediments above 5.5 sec TW are Maestrichtian and younger biogenic oozes which, before the Neogene erosional episode, lay in a smooth bank largely obliterating the topographic distinction between shelf and basin.

A problem, as yet unresolved, follows from the conclusion that at least $0.35 \mathrm{sec}$ TW of sediment from such a bank would have had to have been eroded at Site 330 to produce the present topography, and at least $0.15 \mathrm{sec}$ TW from Site 327. The presence of so much additional overburden should have resulted in greater diagenesis and compaction than is seen of the Paleogene oozes at Site 327 and the Albian claystone at Site 330. It may be that the pre-late Oligocene sea bed was more complex in shape, so that Sites 327 and 330 were less deeply 
buried. It is interesting that a more continuous "bank," which also has suffered greatest submarine erosion directly above the buried shelf break, occurs on the other flank of the basin province, southeast of the Falkland Islands (J. Burrell, unpublished data). Some kind of relationship between the degree of erosion and the effects of differential compaction of shelf and basin sediments may be in operation.

\section{SUMMARY AND CONCLUSIONS}

The process of correlating between the three Falkland Plateau drilling sites by means of the two reflection profiles which pass through them is inevitably imperfect because of gaps in sampling at the sites and the nature of the reflection profiles. Nevertheless, a crude but useful correlation between the sites has been achieved and the identified reflectors traced beyond the sites with varying degrees of confidence. The resulting interpreted time sections yield insights which nowhere contradict the geological history of the region derived from the cores, but confirm and in many cases extend it. The major geological conclusions are:

1) The metamorphic basement cored at Site 330 is a rough, isolated basement high. The Mid-Jurassic marine transgression at the site was part of a general subsidence of the region; the overlying sediments are prograded upslope, and a 1.5 to $2 \mathrm{~km}$ deep basin was already in existence to the south. The basin floor is probably of continental crust, and the basin extends over the central region of the Falkland Plateau-a basin province. The elevated region around the sites was a complementary shelf province.

2) Because of the exposed nature of Site 330 at the time, the conditions of restricted circulation under which Upper Jurassic and Lower Cretaceous sediments were deposited must have applied in addition over the entire basin province. From this it appears unlikely that the other intra-Gondwanaland oceans began to open any earlier than did the South Atlantic.

3) Albian sedimentation, occurring under conditions of improving circulation as a deep seaway connected the South Atlantic and Indian oceans east of the plateau, for the first time failed to build out further the margin between the shelf and basin provinces. The overlying Upper Cretaceous condensed section appears to result from nondeposition, but subordinate submarine erosion may have taken place. The profiles support the suggestion of a generally lowered CCD through the Maestrichtian and Paleocene, the biogenic oozes of those ages thickening upslope.

4) Between Sites 329 and 330 the sea bed is of all ages from late Miocene to Late Cretaceous (preMaestrichtian), as a result of submarine erosion. The disposition of sediments is roughly consistent with steadily increasing bottom current strength through the Cenozoic. It is possible to detect one sudden increase in bottom currents which may result from the opening of Drake Passage in the mid-Cenozoic, but sedimentation along the line of section was subject additionally to other influences, and a certain correlation cannot be made.

5) The elevation southwest of Site 330 is considered also to result from submarine erosion, and the upper $0.5 \mathrm{sec}$ or so of sediment in the basin province is thought to represent redeposition largely of reworked sediments, above a young erosion surface. It is speculated that most of the sediment fill of the basin province is of Maestrichtian and lower Cenozoic biogenic oozes, continuous with those of the shelf province before the late Cenozoic period of submarine erosion.

\section{ACKNOWLEDGMENTS}

The author is grateful to Dr. J.I. Ewing of the LamontDoherty Geological Observatory for release of the unpublished RC 1606 reflection profile which passes through the drill sites. John Burrell reviewed the manuscript and made helpful suggestions. The opportunity to take part in Leg 36 is acknowledged with thanks, as is all the work put in by the Scripps party of shipboard technicians, the Global Marine ship and rig crew, and colleagues in the scientific party in acquiring the underway data and drilling, analyzing, and interpreting the cores.

During the period of this work, the author was supported by a Natural Environment Research Council research contract.

\section{REFERENCES}

Barker, P.F., 1970. Plate tectonics of the Scotia Sea region: Nature, v. 228 , p. 1293-1296.

Barker, P.F., in press. The tectonic framework of Cenozoic volcanism in the Scotia Sea region-A review: Bull. Volc.

Brennecke, W., 1921. Die oceanographischen Arbeiten der Deutschen Antarktischen Expedition 1911-1912 (Deutschland): Deutsche Seewarte Archiv., v. 39, p. 1-216.

Ewing, J.I., Ludwig, W.J., Ewing, M., and Eittreim, S.L., 1971. Structure of the Scotia Sea and Falkland Plateau: J. Geophys. Res., v. 76, p. 7118-7137.

Gill, A.E., 1973. Circulation and bottom water production in the Weddell Sea: Deep-Sea Res., v. 20, p. 111-140.

Hayes, D.E., Frakes, L.A., et al., 1975. Initial Reports of the Deep Sea Drilling Project, Volume 28: Washington (U.S. Government Printing Office).

Larson, R.L. and Ladd, J.W., 1973. Evidence for the opening of the South Atlantic in the Early Cretaceous: Nature, v. 246 , p. $209-212$.

Sclater, J.G., Anderson, R.N., and Bell, M.L., 1971. Elevation of Ridges and Evolution of the Central Eastern Pacific: J. Geophys. Res., v. 76, p. 7888-7915. 